\title{
EFFICACY OF ATRAZINE HERBICIDE FOR MAIZE WEED CONTROL IN NEW ALLUVIAL ZONE OF WEST BENGAL
}

\author{
Moinuddin $\mathrm{G}^{* 1}$, Kundu $\mathrm{R}^{2}$, Jash $\mathrm{S}^{1}$, Sarkar $\mathrm{A}^{1}$, Soren $\mathrm{C}^{3}$ \\ ${ }^{1}$ Regional Research Station, Jhargram, Bidhan Chandra Krishi Viswavidyalaya \\ ${ }^{2}$ AICRP, Groundnut, BCKV, Kalyani, Nadia \\ ${ }^{3}$ Regional Research Sub Station, BCKV, Purulia, West Bengal \\ Received - March 08, 2018; Revision - June 14, 2018; Accepted - July 28, 2018 \\ Available Online - August 10, 2018 \\ DOI: http://dx.doi.org/10.18006/2018.6(4).707.716
}

KEYWORDS
Maize
Herbicide
Atrazine
Weed
Yield

\begin{abstract}
Field study was conducted in during 2015 and 2016 to evaluate the efficacy of new formulation of atrazine herbicide on weed control in maize. The experiment was conducted at Research farm, kalyani of BCKV. The treatment schedule was untreated, Spraying of new formulation atrazine 50\% WP @ 1 $\mathrm{kg} / \mathrm{ha}$, new formulation atrazine 50\%WP @ $2 \mathrm{~kg} / \mathrm{ha}$, new formulation atrazine 50\% WP@ $4 \mathrm{~kg} /$ ha, old formulation atrazine 50\% WP @ $1 \mathrm{~kg} / \mathrm{ha}$ and old formulation atrazine 50\% WP @ $2 \mathrm{~kg} / \mathrm{ha}$. The spraying schedule was started on ten days after sowing. The weed complex consisted of Echinochloa colona, Brachiaria mutica, Digiteria sanguinalis, Elusine indica, Cyperus rotundus, Amaranthus viridis, Digera arvensis, Alternanthera philoxeroides, Phyllanthus niruri etc. However application of new formulation @ 4 kg/ha to maize plot gave lowest weed density, dry matter and highest WCE at 10, 20 and 30 DAA. Application of atrazine 50\% WP (new source) at the higher doses i.e. @ $4 \mathrm{~kg} \mathrm{ha}^{-1}$ gave highest grain yield $(4.37 \mathrm{t} / \mathrm{ha})$, which was statistically at par with the recommended dose i.e. @ $2 \mathrm{~kg} \mathrm{ha}^{-1}$, therefore lower concentration may be preferred over higher concentration. No phytotoxic symptoms were observed in any of the doses of atrazine 50\% WP (new). So atrazine 50\% WP (new source) @ $2 \mathrm{~kg} \mathrm{ha}^{-1}$ may be safely used for effective weed control and better yield of maize.
\end{abstract}

* Corresponding author

E-mail: moinuddin777@ rediffmail.com (Moinuddin G)

Peer review under responsibility of Journal of Experimental Biology and Agricultural Sciences.

Production and Hosting by Horizon Publisher India [HPI] (http://www.horizonpublisherindia.in/).

All rights reserved.
All the article published by Journal of Experimental Biology and Agricultural Sciences is licensed under a Creative Commons Attribution-NonCommercial 4.0 International License Based on a work at www.jebas.org.

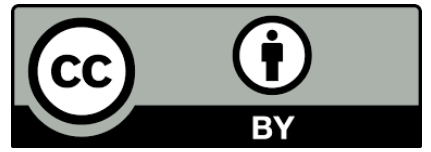




\section{Introduction}

Maize is one of the most important cereal crops in the world agricultural economy both as food for man and feed for animals. It is known as 'Queen of Cereals'. This crop can be cultivated in a wide range of climate from semi arid to sub humid and humid region. Beside this, maize is also utilized as raw material for food sweeteners, pharmaceuticals, beverages industry, film and textile industry, packaging industry etc (Kumar et al., 2012a). Its cultivation is becoming popular as bio fuel agents. Maize is third in the world's cereal production after rice and wheat. In India, it is grown over an area of $8.85 \mathrm{~m}$ ha with total production of $21.81 \mathrm{~m}$ tones (Agricultural statistics, 2016) and it is increasing day by day due its wide adoptability, easy to cultivate and better management practices. Maize, being a heavy feeder of both soil nutrients and moisture, it exhausts the soil heavily. As maize is mostly grown as monoculture, so natural resources are being depleted at a regular manner, as a consequence such cropping practice has created favourable condition for weed infestation (Akobundu et al., 1999). At the same time maize is a widely spaced crop, so the crop becomes infested with variety of weeds and face heavy weed competition, which often inflicts huge crop losses ranging from 50 to $90 \%$ (Akobundu, 1987; Darkwa et al., 2001). The critical stage of crop weed completion in maize crop is 30 to 45 days after crop emergence (Kamble et al., 2005), therefore management of weeds during this period is of great important. Weeds emerge fast, grow rapidly and compete with the crop severally for growth resources viz., nutrients, moisture, sunlight and space during entire vegetative growth and early reproductive stages of maize. The age-old weed management practices followed in maize cultivation such as hand weeding, pulling etc are very much cost intensive. However high cost and unavailability of field labour because of their drift from village to cities make delayed and ineffective weed management in maize. As an alternative chemical weed control may play an important role, as it is cheaper and more effective (Dalal \& Nandkar, 2010). The herbicides available for chemical weed control in maize include pre-emergence application of atrazine, simazine, pendimethalin, alachlor and post-emergence application of 2,4-D (Anonymous 1994). These herbicides are effective against annual grasses and broad leaf weeds but when supplemented with hoeing operation give better control for perennial weeds (Chikoye et al., 2005). Atrazine was first registered in Europe in the year 1959 (Chikoye et al., 2006). After that a number of new formulations came to increase its efficacy. It is necessary to develop effective herbicide for weed control in maize. The improved formulation may reduce the herbicidal dose as compare to existing sources. The objective of this study was to evaluate the efficacy of new formulation of atrazine on weed control in maize.

\section{Materials and Methods}

The experimental site was situated at $22^{\circ} 97^{\prime} \mathrm{N}$ latitude and $88^{\circ} 43^{\prime}$ E longitude with the 9.75 meters above the mean sea level (MSL) and topographically the land was medium in slope having deep tube well facility. The soil of the experimental field was sandy loam in texture with normal $\mathrm{pH}$ and medium fertility status with low water holding capacity. The crop was grown under irrigated condition. The average rainfall is $1500 \mathrm{~mm}$ per annum of which around $70 \%$ rainfall occurs during July to September. The lowest relative humidity is observed in the month of December while the maximum is in July.

\subsection{Agronomic Practice}

The field experiment on the efficacy of atrazine 50\% WP (Candidate product/new source/new formulation) against weed in maize crop was conducted during the kharif season of 2015-16 and 2016-17 in randomized block design with four replications in subtropical climatic condition of West Bengal at Research farm of Kalyani, under Bidhan Chandra Krishi Viswavidyalaya, West Bengal. Excluding the weed management practice, all the recommended improved package of practices of Maize was followed in this experiment including the plant protection measures. One day before sowing, the seeds were treated by using Trichodermaviridis@ $4 \mathrm{~g} \mathrm{~kg}^{-1}$ of Maize seed. The treated seeds were kept under shade for 6 hours before sowing in the field. FYM@ $5 \mathrm{t} \mathrm{ha}^{-1}$ was applied along with full doses of phosphorus through single super phosphate (SSP) and potash through muriate of potash (MOP) each @ $50 \mathrm{~kg} \mathrm{ha}^{-1}$ respectively at basal. Recommended dose of nitrogen @ $120 \mathrm{~kg} \mathrm{ha}^{-1}$ through urea was applied in 3 splits at basal, at knee high stage and at tasseling stage. The variety, $900 \mathrm{M}$ Gold was used as test crop. Plot size of $6 \mathrm{~m} \times 5 \mathrm{~m}$ was used for the experiment and $1 \mathrm{~m}$ spacing was given in between two plots. Three meter isolation distance was maintained around the total experimental area. Planting was done at $65 \times 25 \mathrm{~cm}$ spacing. Then irrigation was applied as when required basis. The treatment schedule was control $\left(\mathrm{T}_{1}\right)$, spraying of new formulation atrazine 50\% WP @ $1 \mathrm{~kg} / \mathrm{ha}\left(\mathrm{T}_{2}\right)$, new formulation atrazine 50\%WP @ $2 \mathrm{~kg} / \mathrm{ha}\left(\mathrm{T}_{3}\right)$, new source atrazine 50\% WP @ $4 \mathrm{~kg} / \mathrm{ha}\left(\mathrm{T}_{4}\right)$, old source atrazine 50\% WP @ $1 \mathrm{~kg} / \mathrm{ha}\left(\mathrm{T}_{5}\right)$ and old source of atrazine 50\% WP @ $2 \mathrm{~kg} / \mathrm{ha}$ $\left(\mathrm{T}_{6}\right)$. The spraying schedule was done as early post emergence (10 DAS).

\subsection{Data Collection and Analysis}

The population and dry weights of dominant weeds were recorded separately at 10, 20 and 30 DAA. For recording both density and dry weight of the weed flora, $50 \mathrm{~cm}$ x $50 \mathrm{~cm}$ quadrate was placed thrice per plot for evaluating the relative efficacy of the test products and the data were presented on $\mathrm{m}^{-2}$ basis. 
Weed control efficiency was calculated based on the data recorded 10,20 and 30 DAA in maize as per the formula given below:

Weed control efficiency $(\mathrm{WCE})=\frac{\mathrm{X}-\mathrm{Y}}{\mathrm{X}} \times 100$

Where, $\mathrm{X}=$ Dry weight of weeds in unweeded plot; $\mathrm{Y}=$ Dry weight of weeds in treated plot.

The grain and stover yield of Maize was recorded after threshing and drying properly.

\section{Results and Discussion}

\subsection{Weed Flora}

In the experimental plots, the dominant grassy weed flora were grasses like Echinochloa colona, Brachiaria mutica, Digiteria sanguinalis, Eleusine indica; sedges like Cyperus rotundus, and broadleaf weed like Amaranthus viridis, Digera arvensis, Alternanthera philoxeroides, Phyllanthus niruri and Trianthama sp etc.

\subsection{Phytotoxicity}

No significant phytotoxic effect was found due to application of new source of atrazine 50\% WP at all application doses (data not shown). Observation was made at 3, 5 and 10 days after application of herbicides.

\subsection{Weed Count}

There was a significant effect of application of new source of atrazine herbicide on number of monocot weeds at 10,20 and 30 DAA (Table 1, 2 and 3). However weed count of monocots was lowest when new source was applied at higher dose i.e. $4 \mathrm{~kg} / \mathrm{ha}$.

Table1 Effect of treatments on weed density $\mathrm{m}^{-2}$ at 10 DAA in Maize

\begin{tabular}{|lccc|ccccc|}
\hline \multicolumn{1}{|c}{ Treatment } & $\begin{array}{c}E . \\
\text { colona }\end{array}$ & $\begin{array}{c}\text { B. } \\
\text { mutica }\end{array}$ & $\begin{array}{c}\text { Digitaria } \\
\text { sp }\end{array}$ & $\begin{array}{c}\text { C. } \\
\text { rotundus }\end{array}$ & $\begin{array}{c}\text { Other } \\
\text { monocots }\end{array}$ & $\begin{array}{c}\text { A. } \\
\text { viridis }\end{array}$ & $\begin{array}{c}\text { D. } \\
\text { arevensis }\end{array}$ & $\begin{array}{c}\text { Other } \\
\text { dicots }\end{array}$ \\
\hline Untreated check & 9.20 & 15.80 & 11.74 & 7.46 & 30.66 & 11.24 & 10.58 & 9.67 \\
\hline Atrazine 50\% WP (new) @ 1 kg/ha & 3.97 & 6.08 & 7.26 & 6.92 & 13.28 & 3.07 & 2.99 & 2.82 \\
\hline Atrazine 50\% WP (new) @ 2 kg/ha & 3.17 & 5.57 & 5.92 & 5.78 & 11.35 & 2.62 & 2.62 & 1.66 \\
\hline Atrazine 50\% WP (new) @ 4 kg/ha & 2.56 & 4.87 & 5.39 & 6.12 & 9.73 & 2.40 & 2.33 & 1.58 \\
\hline Atrazine 50\% WP (old) @ 1 kg/ha & 4.57 & 6.52 & 7.71 & 7.05 & 14.63 & 3.18 & 3.12 & 3.66 \\
\hline Atrazine 50\% WP (old) @ 2 kg/ha & 3.46 & 6.01 & 6.40 & 6.28 & 11.60 & 2.61 & 2.76 & 1.70 \\
\hline SEm ( \pm ) & 0.32 & 0.40 & 0.35 & 0.41 & 0.81 & 0.25 & 0.21 & 0.19 \\
\hline CD 5\% & 0.93 & 1.18 & 1.03 & NS & 2.39 & 0.74 & 0.61 & 0.55 \\
\hline
\end{tabular}

Table 2 Effect of treatments on weed density $\mathrm{m}^{-2}$ at 20 DAA in Maize

\begin{tabular}{|lccc|ccccc|}
\hline \multicolumn{1}{|c}{ Treatment } & $\begin{array}{c}E . \\
\text { colona }\end{array}$ & $\begin{array}{c}B . \\
\text { mutica }\end{array}$ & $\begin{array}{c}\text { Digitaria } \\
s p\end{array}$ & $\begin{array}{c}\text { C. } \\
\text { rotundus }\end{array}$ & $\begin{array}{c}\text { Other } \\
\text { monocots }\end{array}$ & $\begin{array}{c}\text { A. } \\
\text { viridis }\end{array}$ & $\begin{array}{c}\text { D. } \\
\text { arevensis }\end{array}$ & $\begin{array}{c}\text { Other } \\
\text { dicots }\end{array}$ \\
\hline Untreated check & 10.76 & 20.68 & 15.74 & 13.28 & 35.29 & 14.60 & 13.97 & 15.48 \\
\hline Atrazine 50\% WP (new) @ 1 kg/ha & 4.91 & 6.45 & 8.48 & 11.92 & 19.42 & 4.59 & 3.78 & 3.91 \\
\hline Atrazine 50\% WP (new) @ 2 kg/ha & 3.48 & 5.65 & 7.37 & 11.12 & 18.61 & 3.55 & 3.01 & 2.81 \\
\hline Atrazine 50\% WP (new) @ 4 kg/ha & 2.59 & 5.21 & 6.54 & 10.60 & 16.68 & 3.27 & 2.63 & 2.19 \\
\hline Atrazine 50\% WP (old) @ 1 kg/ha & 5.12 & 6.68 & 8.77 & 12.25 & 19.58 & 4.73 & 3.99 & 4.52 \\
\hline Atrazine 50\% WP (old) @ 2 kg/ha & 3.81 & 6.22 & 8.14 & 11.88 & 17.99 & 3.43 & 3.37 & 2.90 \\
\hline SEm ( \pm ) & 0.43 & 0.45 & 0.52 & 0.57 & 0.89 & 0.35 & 0.38 & 0.30 \\
\hline CD 5\% & 1.27 & 1.33 & 1.53 & $\mathrm{NS}$ & 2.61 & 1.02 & 1.11 & 0.88 \\
\hline
\end{tabular}

Journal of Experimental Biology and Agricultural Sciences http://www.jebas.org 
Table 3 Effect of treatments on weed density $\mathrm{m}^{-2}$ at 30 DAA in Maize

\begin{tabular}{|lcccccccc|}
\hline Treatment & $\begin{array}{c}E . \\
\text { colona }\end{array}$ & $\begin{array}{c}\text { B. } \\
\text { mutica }\end{array}$ & $\begin{array}{c}\text { Digitaria } \\
\text { sp }\end{array}$ & $\begin{array}{c}C . \\
\text { rotundus }\end{array}$ & $\begin{array}{c}\text { Other } \\
\text { monocots }\end{array}$ & $\begin{array}{c}\text { A. } \\
\text { viridis }\end{array}$ & $\begin{array}{c}\text { D. } \\
\text { arevensis }\end{array}$ & $\begin{array}{c}\text { Other } \\
\text { dicots }\end{array}$ \\
\hline Untreated check & 13.49 & 26.09 & 23.56 & 17.21 & 40.95 & 21.53 & 19.87 & 21.39 \\
\hline Atrazine 50\% WP (new) @ 1 kg/ha & 5.70 & 8.01 & 10.27 & 15.40 & 24.28 & 5.39 & 6.27 & 6.60 \\
\hline Atrazine 50\% WP (new @ 2 kg/ha & 4.90 & 7.44 & 8.86 & 14.46 & 22.40 & 5.04 & 4.90 & 4.50 \\
\hline Atrazine 50\% WP (new) @ 4 kg/ha & 4.33 & 6.58 & 7.58 & 14.37 & 19.46 & 4.11 & 3.62 & 3.89 \\
\hline Atrazine 50\% WP (old) @ 1 kg/ha & 6.31 & 8.07 & 9.93 & 15.78 & 26.37 & 5.72 & 6.78 & 6.76 \\
\hline Atrazine 50\% WP (old) @ 2 kg/ha & 5.27 & 7.51 & 9.03 & 14.95 & 24.21 & 5.02 & 5.06 & 5.21 \\
\hline SEm ( \pm ) & 0.46 & 0.48 & 0.57 & 0.88 & 1.03 & 0.44 & 0.50 & 0.41 \\
\hline CD 5\% & 1.35 & 1.41 & 1.67 & NS & 3.05 & 1.29 & 1.48 & 1.21 \\
\hline
\end{tabular}

Data represented at Table 1, 2 and 3 indicated that atrazine (new source) at higher dose (4 kg/ha) was most effective against $E$. colona (number of E. Colona 2.56, 2.59 and 4.33) this was followed by B. mutica (4.87, 5.21 and 6.58), Digiteria sp. (5.39, 6.54 and 7.58) at 10, 20 and 30 DAA respectively. The superiority of atrazine in controlling E. colona was reported by Rana et al. (1998) and Kumar et al. (2012b). However the effectiveness of new source of atrazine on control of monocot weeds gradually increased with increasing dose of herbicide. From table 1, 2 and 3, it was quite clear in most cases new source of atrazine was more effective to control monocot weeds as comparison to market product regarding weed count at a certain level of doses i.e. 1, 2 $\mathrm{kg} / \mathrm{ha}$ at 10, 20 and 30 DAS respectively. The effect of atrazine herbicide (new source) on weed count was more or less same with old source of atrazine at a certain dose i.e. $1 \mathrm{~kg}$ or $2 \mathrm{~kg} / \mathrm{ha}$ on all stage i.e. 10, 20, and 30 DAA (Table 1, 2 and 3). However application of new source of atrazine herbicide failed to register any significant effect on weed count of sedge (Table 1, 2, 3). But number of sedge i.e. C. rotundus was lowest (5.78) at 10 DAA when new source was applied @ $2 \mathrm{~kg} / \mathrm{ha}$ (Table 1), whereas at 20 and 30 DAA sedge count was higher (10.60 and 14.37 respectively) with new source applied at @ $4 \mathrm{~kg} / \mathrm{ha}$. Findings of present study was supported the idea of Shehzad et al. (2012) who reported that weed population reduced effectively with different herbicidal doses.

All doses of new source of atrazine herbicide provided significant control of broadleaf weeds like $A$. viridis and $D$. arvensis (Table 1, 2 and 3). Present findings supported the result of Shehzad et al. (2012) and Hejazi et al. (2001) who gave the idea that application of atrazine reduced the crop weed competition. However reduction in number of broadleaf weeds (A. viridis) was highest with application of atrazine at the dose of $4 \mathrm{~kg} / \mathrm{ha}$ closely followed by atrazine (old) @ 2kg/ha, atrazine (new) @ 2kg/ha, atrazine (new) @ 1kg/ha and atrazine (old) @ 1kg/ha at 10,20 and 30 DAS (Table 1, 2 and 3) whereas in case of D. arvensis the order was atrazine (new) @ 2kg/ha, atrazine (old) @ 2kg/ha, atrazine (new) @1 kg/ha and atrazine (old) @ 1kg/ha at 10,20 and 30 DAS (Table 1, 2 and 3).

From the Table 2, it had been observed that increase in weed count (grass) from 10 DAA to 20 DAA was highest $(21.33 \%$ ) in case of Digiteria sp. and lowest (1.17\%) for E. colona due to application of new source @ $4 \mathrm{~kg} / \mathrm{ha}$ that implied time bound control of atrazine (new source) for E. Colona weed during this 10 days period. But at 30 DAS, new source of atrazine @ $4 \mathrm{~kg} / \mathrm{ha}$ was most effective against Digiteria sp. (count increase $15.90 \%$ ) among the grasses (Table 2). The efficiency of atrazine herbicide as pre-emergence against Digiteria was proven by the findings of Sharma et al (2000). For broadleaf weed, weed density increase was highest for Amaranthus (36.25\%) at 20 DAA (Table 2) and lowest for Digera arvensis, but at 30 DAS it was just reverse (Table 3). Reduction in weed density by application atrazine was reported by Patel et al. (2000), Kumar et al. (2012a) and Rana et al. (1998).

\subsection{Weed Dry Matter}

From figure 1 it is quite clear that there was a significant relation between the atrazine herbicide dose (both new and old product) and the dry matter production of monocots weed. At 10, 20 and 30 DAA, weed dry matter production was lowest for all monocots and dicots when atrazine (new source) was applied @ 4 kg/ha (Fig $2,3,4,5$ and 6). In case of monocot weeds, application of atrazine herbicide (new source) @ $4 \mathrm{~kg} / \mathrm{ha}$ was most effective in controlling Digiteria sp in terms of dry matter production followed by E. colona, B. mutica at 10 DAA (Fig. no. 1). Whereas, at 20, 30 DAA the sequence was E. colona, Digiteria sp and Brachiarea mutica (Figure 2 and 3). This may be due to the prolonged efficacy of atrazine herbicide when applied particularly 


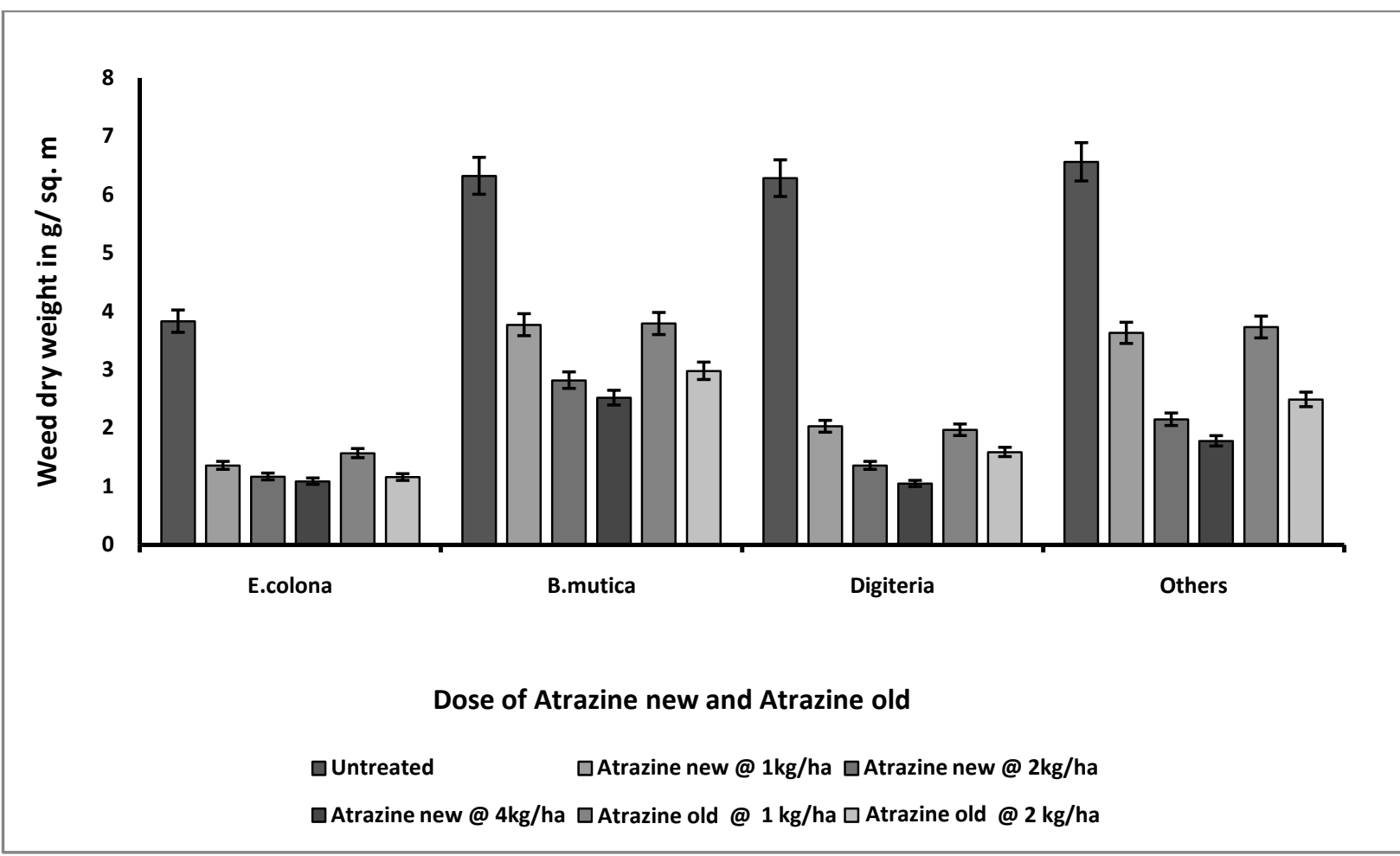

Figure 1 Effect of Atrazine herbicide on monocot weed dry matter at 10 DAA

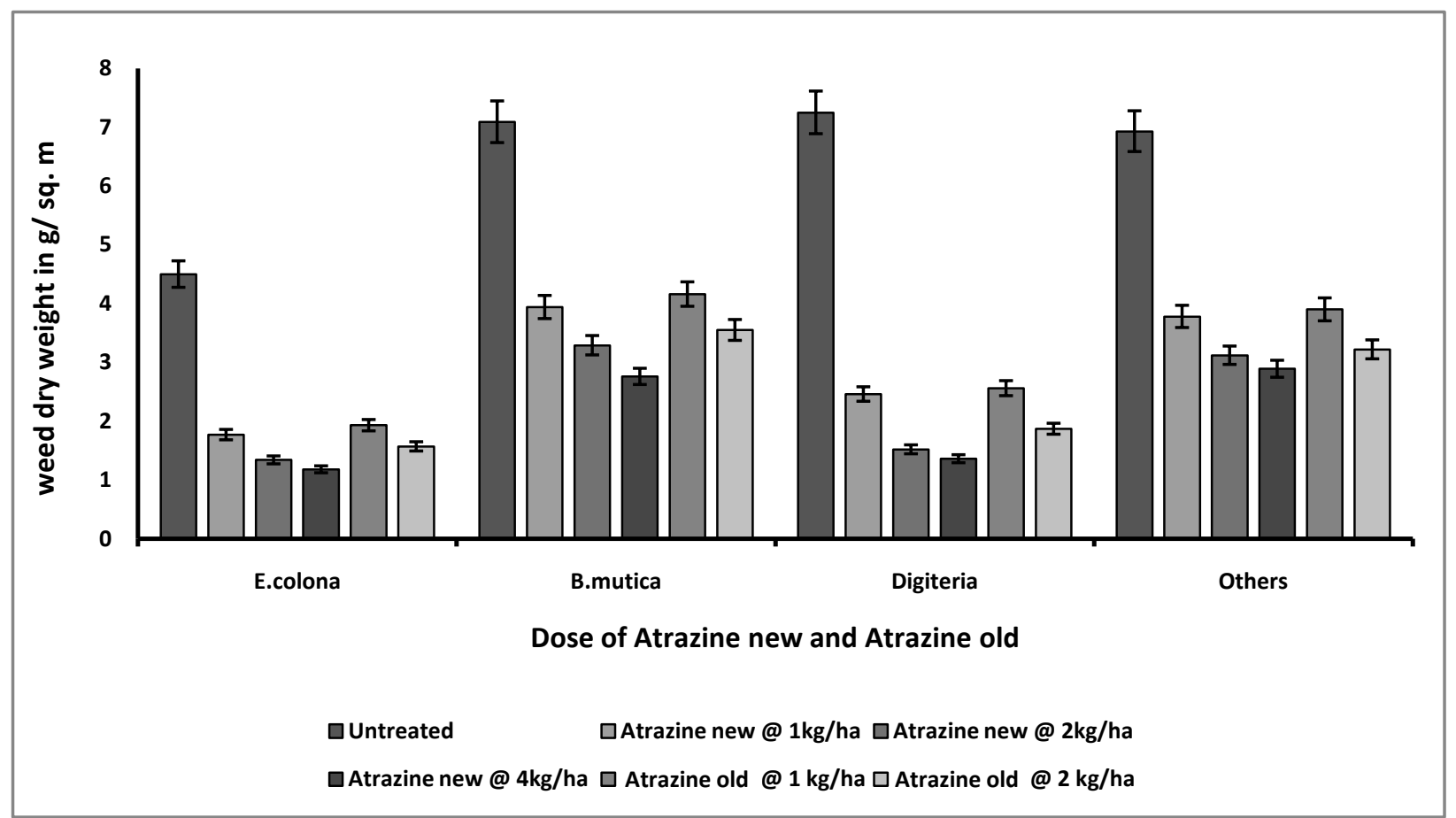

Figure 2 Effect of Atrazine herbicide on monocot weed dry matter at 20 DAA

Journal of Experimental Biology and Agricultural Sciences http://www.jebas.org 


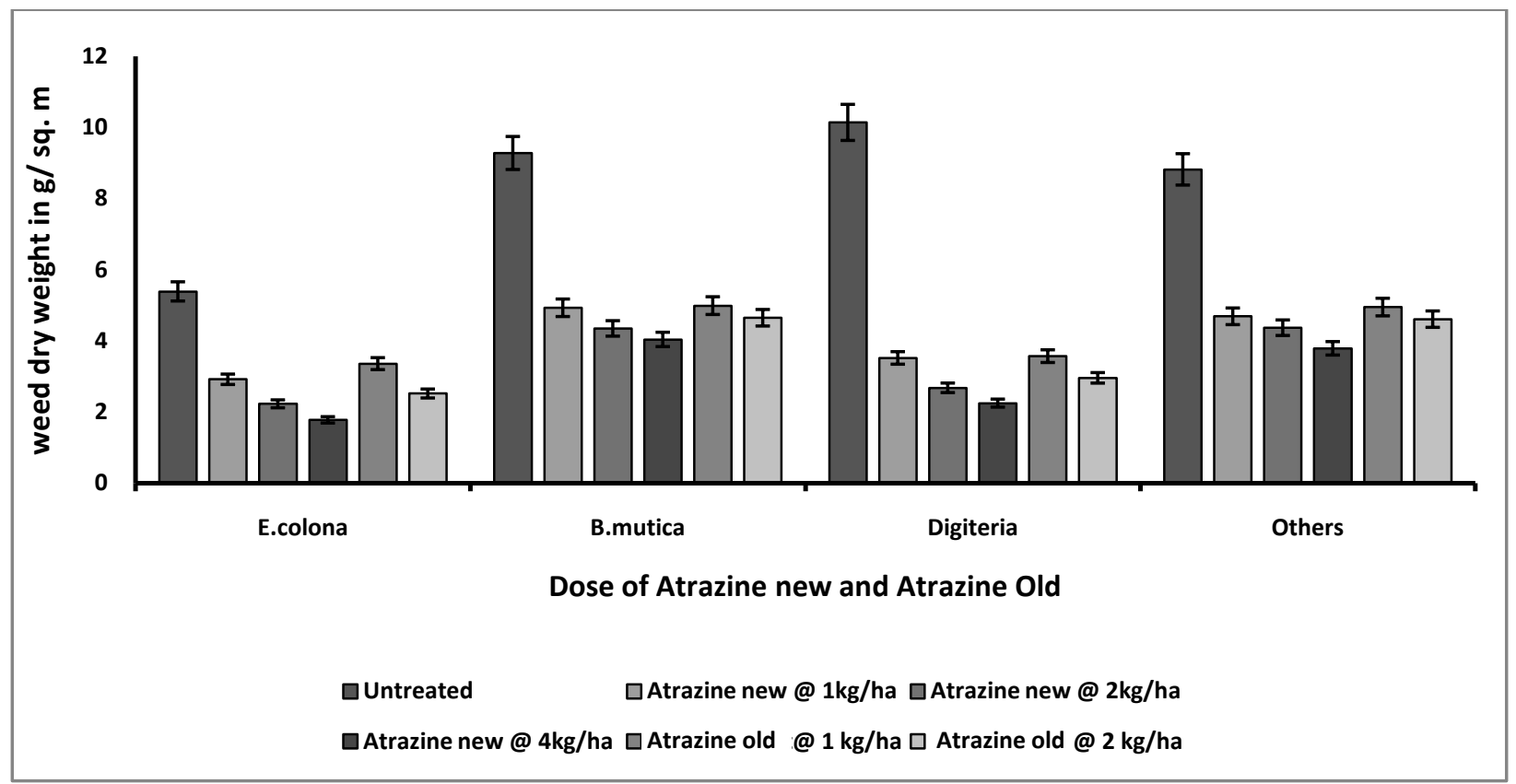

Figure 3 Effect of Atrazine herbicide on monocot weed dry matter at 30 DAA

Table 4 Effect of treatments on weed dry weight $\left(\mathrm{g} \mathrm{m}^{-2}\right)$ at 10 DAA in Maize

\begin{tabular}{|ccccccccc|}
\hline Treatment & $\begin{array}{c}E . \\
\text { colona }\end{array}$ & $\begin{array}{c}\text { B. } \\
\text { mutica }\end{array}$ & $\begin{array}{c}\text { Digitaria } \\
s p\end{array}$ & $\begin{array}{c}C . \\
\text { rotundus }\end{array}$ & $\begin{array}{c}\text { Other } \\
\text { monocots }\end{array}$ & $\begin{array}{c}\text { A. } \\
\text { viridis }\end{array}$ & $\begin{array}{c}D . \\
\text { arevensis }\end{array}$ & $\begin{array}{c}\text { Other } \\
\text { dicots }\end{array}$ \\
\hline Untreated check & 3.83 & 6.32 & 6.28 & 1.58 & 6.56 & 5.65 & 6.40 & 4.53 \\
\hline Atrazine 50\% WP (new) @ 1 kg/ha & 1.36 & 3.77 & 2.03 & 1.50 & 3.63 & 2.25 & 2.43 & 1.96 \\
\hline Atrazine 50\% WP (new) @ 2 kg/ha & 1.17 & 2.82 & 1.36 & 1.34 & 2.15 & 1.59 & 1.94 & 1.37 \\
\hline Atrazine 50\% WP (new) @ 4 kg/ha & 1.09 & 2.52 & 1.05 & 1.32 & 1.78 & 1.45 & 1.76 & 1.28 \\
\hline Atrazine 50\% WP (old) @ 1 kg/ha & 1.57 & 3.79 & 1.97 & 1.49 & 3.73 & 2.49 & 2.53 & 2.10 \\
\hline Atrazine 50\% WP (old) @ 2 kg/ha & 1.16 & 2.98 & 1.59 & 1.36 & 2.49 & 1.67 & 2.17 & 1.46 \\
\hline SEm ( \pm ) & 0.08 & 0.19 & 0.12 & 0.10 & 0.26 & 0.14 & 0.17 & 0.11 \\
\hline CD 5\% & 0.24 & 0.55 & 0.37 & NS & 0.77 & 0.41 & 0.51 & 0.32 \\
\hline
\end{tabular}

at higher dose. This action in turn checks weed growth by depleting the carbohydrate reserves of germinated weeds that lowers photosynthetic activity of weeds. This result was in accordance with the findings of Bollman et al. (2008) and Roy et al. (2008). In all the cases weed dry matter decreased with increase of atrazine dose (new).The effect of atrazine herbicide (both new and old) at application dose $2 \mathrm{~kg} / \mathrm{ha}$ was more or less same against weed dry matter weight of E. colona and B. mutica and Digitaria sp. at 10, 20 \& $30 \mathrm{DAA}$ (Table 4, 5, 6). Application of atrazine herbicide failed to register any significant effect on weed dry matter production of sedges (Table 4, 5, 6) at all stages. Application of atrazine herbicide (new source) @ $4 \mathrm{~kg} / \mathrm{ha}$ gave lowest dry matter weight of broad leaf weeds like A. viridis followed by $D$. arvensis at all stages i.e. $10,20 \& 30$ DAA (Figure $4,5 \& 6$ ). In most of the cases, new source of atrazine herbicide@1 kg/ha and $2 \mathrm{~kg} / \mathrm{ha}$ was as effective as market product at same dose against dry matter accumulation (Figure 4, $5 \& 6$ ). At 10, $20 \& 30$ DAA, the entire untreated plot 
Table 5 Effect of treatments on weed dry weight $\left(\mathrm{g} \mathrm{m}^{-2}\right)$ at 20 DAA in Maize

\begin{tabular}{|lcccccccc|}
\multicolumn{1}{c}{ Treatment } & $\begin{array}{c}E . \\
\text { colona }\end{array}$ & $\begin{array}{c}\text { B. } \\
\text { mutica }\end{array}$ & $\begin{array}{c}\text { Digitaria } \\
\text { sp }\end{array}$ & $\begin{array}{c}\text { C. } \\
\text { rotundus }\end{array}$ & $\begin{array}{c}\text { Other } \\
\text { monocots }\end{array}$ & $\begin{array}{c}\text { A. } \\
\text { viridis }\end{array}$ & $\begin{array}{c}\text { D. } \\
\text { arevensis }\end{array}$ & $\begin{array}{c}\text { Other } \\
\text { dicots }\end{array}$ \\
\hline Untreated check & 4.50 & 7.09 & 7.25 & 3.11 & 6.93 & 6.32 & 6.87 & 5.55 \\
\hline Atrazine 50\% WP (new) @ 1 kg/ha & 1.77 & 3.94 & 2.46 & 2.82 & 3.78 & 2.77 & 2.60 & 2.53 \\
\hline Atrazine 50\% WP (new) @ 2 kg/ha & 1.34 & 3.29 & 1.52 & 2.56 & 3.12 & 1.72 & 2.32 & 2.30 \\
\hline Atrazine 50\% WP (new) @ 4 kg/ha & 1.18 & 2.76 & 1.36 & 2.36 & 2.89 & 1.53 & 1.91 & 2.05 \\
\hline Atrazine 50\% WP (old) @ 1 kg/ha & 1.93 & 4.16 & 2.56 & 2.96 & 3.90 & 2.74 & 2.77 & 2.76 \\
\hline Atrazine 50\% WP (old) @ 2 kg/ha & 1.57 & 3.55 & 1.87 & 2.53 & 3.22 & 1.86 & 2.45 & 2.33 \\
\hline SEm ( \pm ) & 0.14 & 0.28 & 0.18 & 0.21 & 0.27 & 0.19 & 0.23 & 0.15 \\
\hline CD 5\% & 0.41 & 0.83 & 0.53 & NS & 0.81 & 0.55 & 0.68 & 0.43 \\
\hline
\end{tabular}

Table 6 Effect of treatments on weed dry weight $\left(\mathrm{g} \mathrm{m}^{-2}\right)$ at 30 DAA in Maize

\begin{tabular}{|lcccccccc|}
\multicolumn{1}{|c}{ Treatment } & $\begin{array}{c}\text { E. } \\
\text { colona }\end{array}$ & B. mutica & $\begin{array}{c}\text { Digitaria } \\
\text { sp }\end{array}$ & $\begin{array}{c}\text { C. } \\
\text { rotundus }\end{array}$ & $\begin{array}{c}\text { Other } \\
\text { monocots }\end{array}$ & $\begin{array}{c}\text { A. } \\
\text { viridis }\end{array}$ & $\begin{array}{c}\text { D. } \\
\text { arevensis }\end{array}$ & $\begin{array}{c}\text { Other } \\
\text { dicots }\end{array}$ \\
\hline Untreated check & 5.39 & 9.28 & 10.14 & 7.02 & 8.82 & 8.51 & 9.76 & 7.39 \\
\hline Atrazine 50\% WP (new) @ 1 kg/ha & 2.92 & 4.93 & 3.32 & 6.56 & 4.69 & 3.11 & 5.69 & 3.82 \\
\hline Atrazine 50\% WP (new) @ 2 kg/ha & 2.23 & 4.35 & 2.68 & 6.31 & 4.37 & 2.61 & 3.80 & 3.23 \\
\hline Atrazine 50\% WP (new) @ 4 kg/ha & 1.78 & 4.04 & 2.25 & 6.22 & 3.79 & 2.56 & 3.56 & 3.05 \\
\hline Atrazine 50\% WP (old) @ 1 kg/ha & 3.36 & 4.99 & 3.57 & 6.80 & 4.95 & 3.43 & 6.23 & 3.96 \\
\hline Atrazine 50\% WP (old) @ 2 kg/ha & 2.52 & 4.65 & 2.96 & 6.76 & 4.61 & 2.85 & 4.79 & 3.12 \\
\hline SEm ( \pm ) & 0.26 & 0.29 & 0.27 & 0.43 & 0.29 & 0.21 & 0.31 & 0.23 \\
\hline CD 5\% & 0.77 & 0.86 & 0.79 & NS & 0.85 & 0.61 & 0.90 & 0.69 \\
\hline
\end{tabular}

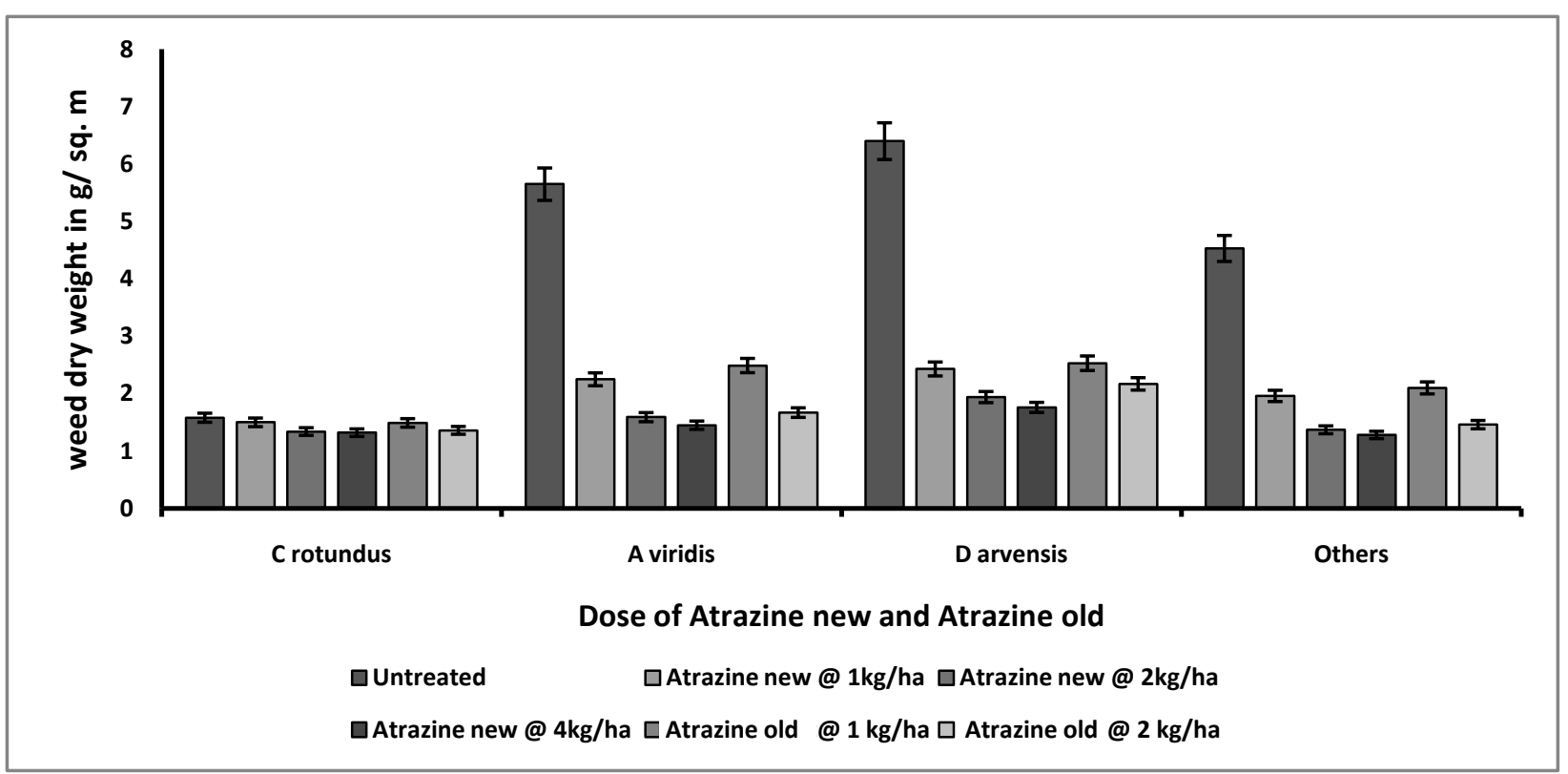

Figure 4 Effect of Atrazine herbicide on sedges \& broad leaf weed dry matter at 10 DAA

Journal of Experimental Biology and Agricultural Sciences

http://www.jebas.org 


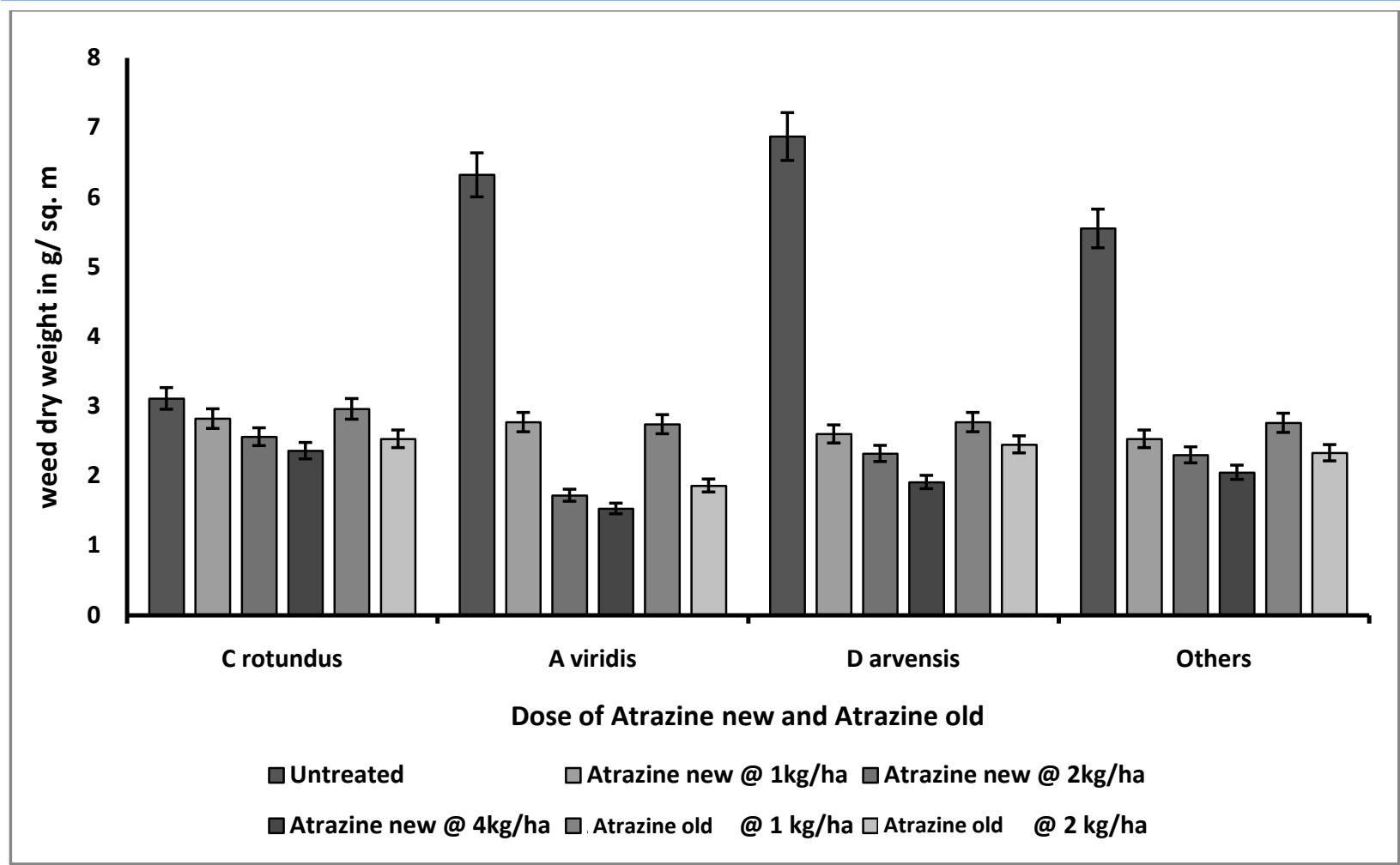

Figure 5 Effect of Atrazine herbicide on sedges \& broad leaf weed dry matter at 20 DAA

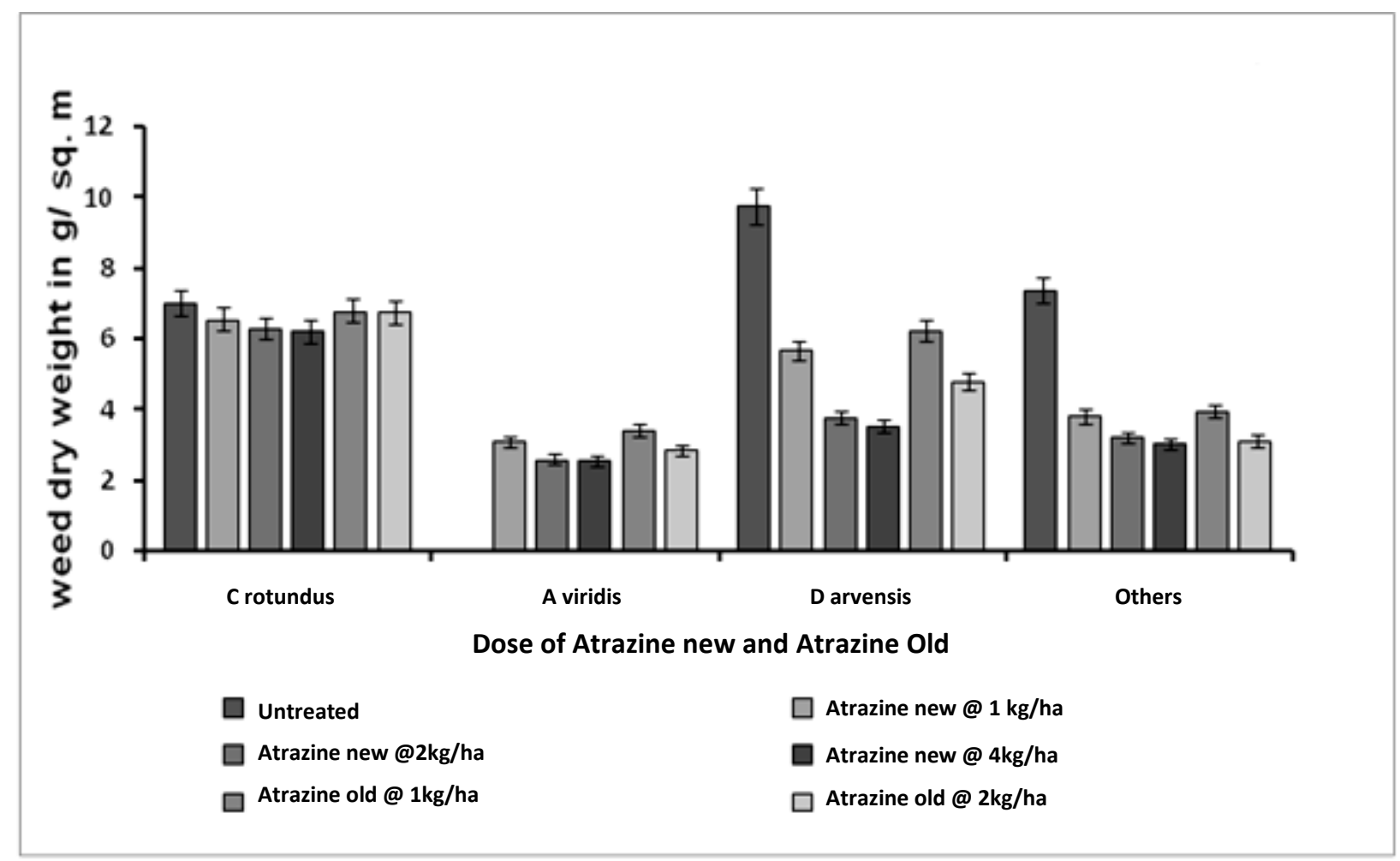

Figure 6 Effect of Atrazine herbicide on sedges \& broad leaf weed dry matter at 30 DAA

Journal of Experimental Biology and Agricultural Sciences http://www.jebas.org 
Table 7 Effect of treatments on weed control efficiency $(\%)$ and yield $\left(t \mathrm{th}^{-1}\right)$ of Maize

\begin{tabular}{|c|c|c|c|c|c|c|}
\hline \multirow{2}{*}{ Treatment } & \multicolumn{3}{|c|}{ Weed control efficiency $(\%)$} & \multicolumn{2}{|c|}{ Yield $\left(\mathrm{tha}^{-1}\right)$} & \multirow{2}{*}{ Harvest index (\%) } \\
\hline & $10 \mathrm{DAA}$ & $20 \mathrm{DAA}$ & 30 DAA & Seed yield & Stover yield & \\
\hline Untreated check & --- & -- & --- & 2.69 & 3.91 & 40.76 \\
\hline Atrazine 50\%WP (new) @ 1 kg/ha & 54.00 & 52.39 & 47.16 & 3.61 & 4.16 & 46.46 \\
\hline Atrazine 50\% WP (new) @ 2 kg/ha & 66.61 & 61.84 & 55.39 & 4.12 & 4.78 & 46.29 \\
\hline Atrazine 50\% WP (new) @ 4kg/ha & 70.23 & 66.32 & 58.91 & 4.37 & 5.02 & 46.54 \\
\hline Atrazine 50\% WP (old) @ 1 kg/ha & 52.20 & 50.06 & 43.76 & 3.59 & 4.21 & 46.03 \\
\hline Atrazine $50 \%$ WP (old) @ 2 kg/ha & 63.84 & 59.30 & 51.35 & 4.06 & 4.72 & 46.24 \\
\hline $\operatorname{SEm}( \pm)$ & --- & --- & --- & 0.17 & 0.23 & --- \\
\hline $\mathrm{CD} 5 \%$ & --- & --- & --- & 0.51 & 0.67 & --- \\
\hline
\end{tabular}

showed highest dry matter production as expected. Higher weed dry matter production might cause more weed population as found in untreated plot and vice versa for treated plot (Pradeep et al., 2017).

\subsection{Weed Control Efficiency (WCE)}

Table 7 presented that application of new source of atrazine @ 4 $\mathrm{kg} / \mathrm{ha}$ gave highest WCE of 70.23, 66.32 and 58.91 at 10, 20 and 30 DAA respectively. Higher WCE due to atrazine application was reported by Singh et al. (2003). Further, result of study also revealed that WCE decreased with advance of crop age at all herbicidal dose. Data obtained from study indicated that new source of atrazine produced the minimum weed population and weed biomass that gave higher WCE. These results were in corroboration with the findings of Bajaya et al. (2015).

\subsection{Grain and Straw Yield}

From this experiment it was observed that grain yield of maize varied significantly among the treatments (Table 7). Untreated plots gave lowest yield (2.69 t/ha). New formulation of atrazine @ $4 \mathrm{~kg} / \mathrm{ha}$ achieved higher grain yield (4.37 t/ha) followed by application of atrazine (new) @ $2 \mathrm{~kg} / \mathrm{ha}$, atrazine (old) @ $2 \mathrm{~kg} / \mathrm{ha}$, atrazine (new) @1 kg/ha and atrazine (old) @ 1kg/ha respectively. This might be due to better inhibition of weed germination therefore more physiological activity of maize plants that imparted higher translocation of photosynthetic products from source to sink during the crop periods. This result confirmed the findings of Billore et al., (1998). Due to application of atrazine (new) grain yield was increased from 34 to $62 \%$ as compare to non treated plot. However yield obtained from plot treated with atrazine (new source) @ 2kg/ha was more or less same with yield obtained from the plot treated with $2 \mathrm{~kg} / \mathrm{ha}$ (old) (Table 7). Lower dose of new formulation produced maize grain yield similar to the old formulation, confirming that new formulation is equally effective at lower application dose. This result reflected the idea of Chikoye et al. (2005). Stover yield was highest (5.02 t/ha) with application of new source of atrazine herbicide@ $4 \mathrm{~kg} / \mathrm{ha}$ (Table 7) and it was more or less similar with lower dose $2 \mathrm{~kg} / \mathrm{ha}$. Harvest index (H.I) was recorded highest with application of new source of Atrazine herbicide @ $4 \mathrm{~kg} / \mathrm{ha}$ (Table 7).

\section{Conclusion}

Result of this study inferred that the weed flora in maize field can be controlled very effectively by applying atrazine 50\% WP (new source) at the higher doses i.e. @ $4 \mathrm{~kg} \mathrm{ha}^{-1}$, which was more or less same with the recommended dose i.e. @ $2 \mathrm{~kg} \mathrm{ha}^{-1}$, therefore lower concentration may be preferred over higher concentration. Regarding yield advantage there is only 6\% higher yield obtained at higher dose i.e. $4 \mathrm{~kg} / \mathrm{ha}$ over lower dose i.e. $2 \mathrm{~kg} / \mathrm{ha}$ (new source). Again, the standard dose of atrazine 50\% WP (new source) @ $2 \mathrm{~kg} \mathrm{ha}^{-1}$ always showed the better result than atrazine $50 \%$ WP (old source) @ $2 \mathrm{~kg} \mathrm{ha}^{-1}$. No phytotoxic symptoms were observed in any of the doses of atrazine 50\% WP (new source) including double of the recommended dose and so, atrazine 50\% WP (new source) @ $2 \mathrm{~kg} \mathrm{ha}^{-1}$ may be safely used for the effective weed control and better yield of maize.

\section{Conflict of Interest}

Authors would hereby like to declare that there is no conflict of interests that could possibly arise.

\section{References}

Akobundu IO (1987) Weed science in the tropics principles and practice. Wiley, Chichester, Great Britain 522 app. 
Akobundu IQ, Ekeleme F, Chikoye D (1999) Influence of fallow management system and frequency of cropping on weed growth and crop yield. Weed Research 39: 241-256.

Anonymous (1994) Weed Control Recommendation for Nigeria. Weed control Series No. 3.The National Advisory Committee on Weed Control, Ibadan, Nigeria, Pp. 100.

Bajya DR, Parween T, Lakharan, MC, Raza, SK (2015) Efficacy of new formulation of triasulfuron on weeds in wheat (Triticum aestivum) and their residual effects on succeeding maize (Zea mays). Indian Journal of Agronomy 60: 57-60.

Billore SD, Joji OP, Ramesh A (1998) Comparative efficacy of herbicide in Soybean. Pestology 11: 60-61.

Bollman JD, Boerbcom CM, Becker RL and Fritz VA (2008) Efficacy and tolerance to HPPD inhibiting herbicides in sweet corn. Weed Technology 22: 666-674.

Chikoye David, Udensi E, Udensi A, Fontem Lum (2005) Evaluation of a new formulation of atrazine and metolachlor mixture for weed control in maize in Nigeria. Crop Protection 24: 1016-1020.

Chikoye David, Udensi E, Udensi A, Fontem Lum (2006) Performance of a new formulation of atrazine for weed control in maize in Nigeria. Journal of Food, Agriculture and Environment 4: 114-117.

Dalal LP, Nandkar PB (2010) Effect of biofertilizers and NPK on Abelmoschus esculentus L. in relation to fruit yield. The Bioscan 5: 309-311.

Darkwa EO, Jhonson BK, Nyalemegbe K, Yangyuoru M, Oti Boateng C, Wilcos TJ, Terry PJ (2001) Weed management on Vertisol for small scale farmers in Ghana. International Journal of Pest Management 47: 299-303.

Agricultural statistics (2016) Department of Agriculture and Cooperation, Ministry of Agriculture and Farmers Welfare, Department Economics and Statistics. Agricultural statistics at a glance 2016, Pp-78.

Hejazi A, Namyouyan S, Rahimiyan H (2001) Critical period of weed control in silage corn (Zea mays). Agricultural Science and Technology 15: 79-86.
Kamble TC, Kakade SU, Nemade SU, Pawar RV, Apotikar VA (2005) Integrated weed management in hybrid maize. Crop Research 29: 396-400.

Kumar B, Chikkappa GK, Jat SL, Parihar CM, Yathish KR, Singh V, Hooda KS, Dass AK, Mukri G, Sekhar JC, Kumar R, Sai Kumar R (2012a) Maize biology: An Introduction, Technical Bulletin, 2012/2. Directorate of Maize Research, Indian Council of Agricultural Research, New Delhi, Pp 32.

Kumar S, Rana SS, Chander N, Angiras NN (2012b) Management of handy weeds in maize under mid-hill condition of Himachalpradesh. Indian Journal of Weed Science 44:11-17.

Patel GN, Patel GJ, Goy SN, Patel BG (2000) Integrated weed management in rabi maize. Gujarat Agricultural University Research Journal 88-90.

Pradeep LS, Girijesg GK, Sharanabasappa, Narayan SM, Natarju SP (2017) Efficacy of pre-emergence herbicides on weed dynamics and yield of maize (Zea mays L.). International Journal of Pure and Applied Bio Science 5: 629-635.

Rana SS, Sharma JJ, Manuja S (1998) Evaluation of promoting herbicide mixture for weed control in Maize (Zea mays L.). New Agriculturist $9: 1-5$.

Roy DK, Singh D, Sinha NK, Pandy DN (2008) Weed management in winter maize + potato intercropping system. Indian Journal of Weed Science 40: 41-43.

Sharma AR, Toor AS, Sur H (2000) Effect of interculture operations and scheduling of atrazine application on weed control and productivity of rain fed maize (Zea mays L.) in Shiwalik foot hills of Punjab. Indian Journal of Agricultural Sciences 70:757-761.

Shehzad MA, Maqsood MA, Anawar Ul Haq, Niaz A (2012) Efficacy of various herbicides against Weeds in Wheat (Triticum aestivum L.). African journal of Biotechnology 11: 791-99.

Singh P, Vargees K, Dawson J (2003) Efficacy of alachlor and atrazine independently and in combination for control of weeds in winter maize (Zea mays L.) var Ganga Safed- 2 Proc. Biennial Conference of ISWS Mach 12-14: 18 